\title{
Two steps forward, one step back: politicisation of the Human Rights Council
}

Article

Accepted Version

Freedman, R. and Houghton, R. (2017) Two steps forward, one step back: politicisation of the Human Rights Council. Human Rights Law Review, 17 (4). pp. 753-769. ISSN 17441021 doi: https://doi.org/10.1093/hrlr/ngx027 Available at https://centaur.reading.ac.uk/69082/

It is advisable to refer to the publisher's version if you intend to cite from the work. See Guidance on citing.

To link to this article DOI: http://dx.doi.org/10.1093/hrlr/ngx027

Publisher: Oxford University Press

All outputs in CentAUR are protected by Intellectual Property Rights law, including copyright law. Copyright and IPR is retained by the creators or other copyright holders. Terms and conditions for use of this material are defined in the End User Agreement.

\section{www.reading.ac.uk/centaur}

\section{CentAUR}

Central Archive at the University of Reading

Reading's research outputs online 


\title{
Two Steps Forward, One Step Back: Politicisation of the Human Rights Council
}

\author{
Rosa Freedman* \& Ruth Houghton*
}

KEYWORDS: United Nations, Human Rights Council, politicisation, Universal Periodic Review.

\section{INTRODUCTION}

Political objectives will always be involved where a body or organisation is intergovernmental and where, rather than being composed of independent experts, government delegates represent their states. The government delegates at the UN Human Rights Council ('Council') are responsible and accountable to their national governments rather than to the UN. ${ }^{1}$ Oberleitner remarks that it is unsurprising and somewhat inevitable that an intergovernmental body comprised of state representatives acts along political lines. ${ }^{2}$ Politicisation of international organisations has been defined as introducing unrelated controversial issues into the body. ${ }^{3}$ The difference between politics and politicisation hinges on the extent to which national objectives are related to the subject matter at hand. Of course, states will always seek to advance national objectives, but pernicious politicisation occurs when states introduce unrelated objectives that undermine the body's mandate. Extreme politicisation may result in bodies losing credibility, becoming ineffective, or even delegitimising their own processes. ${ }^{4}$

The Council has been politicised from its outset. Politicisation has been apparent through states advancing unrelated political objectives, groups shielding their allies from Council scrutiny, and politically-motivated attacks on some states that have obstructed similar action being taken on other, needed, situations. ${ }^{5}$ The Council's structure and composition contributes to its politicisation. The frequent use of group tactics, such as repetitious statements, bloc voting, and vote-bartering, ${ }^{6}$ undermines the legitimacy of some, if not many, Council discussions and actions. Such

* Rosa Freedman is Professor of Law, Conflict and Global Development and Director of the Global Development Division at the University of Reading.

* Ruth Houghton is a Research Assistant and PhD Candidate at Durham Law School, Durham University.

${ }^{1}$ Gibson, International Organizations, Constitutional Law and Human Rights (1991) at 107.

2 Oberleitner, Global Human Rights Institutions (2007) at 47.

3 Lyons, Baldwin and McNemar, 'The "Politicization" Issue in the UN Specialized Agencies' (1977) 32(4)

Proceedings of the Academy of Political Science 81 at 89.

${ }^{4}$ Keohane and Nye 'World Politics and the International Economic System', in Bergsten (ed), The Future of

International Economic Order: An Agenda for Research (1973) 115 at 116-18.

5 Freedman, Failing to Protect: The United Nations and the Politicisation of Human Rights (2014) at Chapter 6.

${ }^{6}$ Cf. Cox, 'State interests and the creation and functioning of the United Nations Human Rights Council' (2016) 6

Journal of International Law and International Relations 87-120. 
politicisation also threatens mechanisms related to the Council. Recently there have been signs of the Council being used to politicise and undermine the Special Procedures system. ${ }^{7}$ Assessment of the Council's first decade must entail scrutiny of the extent to which politicisation undermines the body fulfilling its mandate. Criticising the Council in this regard does not negate the body's positive achievements, but it is important to identify the politicisation issues in order to suggest methods for improvement. Whilst there have been a number of institutional reforms which attempt to reduce politicisation, there are prevailing fault lines that are a result of systemic weaknesses and cannot be ignored.

Throughout the Council's early years it seemed as though the new body would be little more than old wine in new bottles. ${ }^{8}$ The selectivity, bias and politicisation manifested somewhat differently than at the Commission, but it was no less pervasive or pernicious. Many states, observers, scholars and civil society organisations sounded the death knells for a body that was only just created. The Council's credibility was undermined by the excessive focus on Israel, by events like the Special Session on Sri Lanka in $2009,{ }^{9}$ and by its failure even to mention human rights abuses linked to the Beijing Olympics or to the Russian incursions in Georgia and South Ossetia. The turning point came with the Arab Spring uprisings in 2010 and the fracturing of the Organisation Of Islamic Cooperation (OIC), the dominant political bloc at the Council. ${ }^{10}$

The Council seemingly became less politicised with a second wave of membership after the Arab Spring began. Fragmented regional groups and political blocs, largely owing to disunity and disharmony amongst the OIC, led to greater cross-regional co-operation. Between the Council's $19^{\text {th }}$ and $21^{\text {st }}$ Sessions Israel was raised less in discussions, ${ }^{11}$ and fewer tactics were used to divert attention away from other human rights abuses. ${ }^{12}$ Instead the Council devoted more time to discussing the Arab states, ${ }^{13}$ resulting in an increase in the number of resolutions on

\footnotetext{
7 Nolan, Freedman and Murphy (eds), The United Nations Special Procedures System (Brill, 2017).

${ }^{8} \mathrm{~A}$ term used by Schrijver in his article about the Council's early sessions. Schrijver, 'The UN Human Rights Council: A New 'Society of the Committed' or Just Old Wine in New Bottles' (2007) 20(4) Leiden Journal of International Law 809.

9 See Section 5 below.

10 Freedman, 'The United Nations Human Rights Council: More of the Same?' (2013) 31(3) Wisconsin International Law Journal 208 at 241, 243.

11 Human Rights Watch, Keeping the Momentum: One year in the life of the UN Human Rights Council September 2011 at 3.

12 Scannella and Splinter, 'The United Nations Human Rights Council: A Promise to be Fulfilled' (2007) 7(1) Human Rights Law Review 41 at 61 . Compare the agendas from the $13^{\text {th }}$ Session and the $19^{\text {th }}$ Session. This empirical evidence does not allow for the time spent in discussion on Israel in other sessions.

13 For example, a full three hour session dedicated to Syria in the $21^{\text {st }}$ Session compared with the half an afternoon session at the $18^{\text {th }}$ Session. See 'Programme of Work for the $18^{\text {th }}$ Session of the Human Rights Council (12-30 September 2011)' and 'Draft Programme of Work for the $21^{\text {st }}$ Session of the Human Rights Council (10-28 September 2012)'.
} 
those states. ${ }^{14}$ At the same time the US began to engage with the Council, and many of the more moderate states, particularly from Latin America and Africa, found their voices. During those years the Council was more able to focus on fulfilling its mandate through a range of activities. Regular sessions included panels and discussions on emerging human rights issues, ${ }^{15}$ and regional groups and political blocs became less polarised from one another and took joint, effective actions to protect and promote rights such as cross-regional initiatives to sponsor resolutions on new mechanisms and emerging human rights.

These steps forward demonstrate that the Council's potential may be harnessed. A membership composed of more moderate states was crucial to this improved atmosphere, as was a clearer understanding of the institution's working methods that had been negotiated and produced during the Council's early sessions. Despite those strides forward, politicisation persisted in relation to some key issues. Selectivity in the Council's dealings with Syria, ${ }^{16}$ as compared with other similar situations in the Middle East, is one significant example of how the Council ignored its founding principles in terms of country situations. Others include the Council's treatment of Lesbian, Gay, Bisexual and Transgender (LGBT) rights, ${ }^{17}$ and the treatment of non-governmental organisations (NGOs) who raised concerns regarding the human rights records of dominant states. ${ }^{18}$ In particular, the attempt by the International Service for Human Rights (ISHR) to use an intervention to draw attention to reprisals against a human rights defender in China, ${ }^{19}$ as well as repeated attempts by UN Watch to draw attention to the gross politicisation of the Council against Israel, have effectively been silenced by states selectively using procedural points to interrupt and undermine their interventions. ${ }^{20}$ In the sections that follow we address some of the key sites for politicisation at the Council, exploring how politicisation has been manifested, its impact upon the body's work and credibility,

\footnotetext{
${ }^{14}$ There were 8 resolutions adopted on the situation in Syria between April 2012 and June 2012.

${ }^{15}$ For example, South Africa and Brazil led a panel on Human Rights, sexual orientation and gender identity (7 March, $19^{\text {th }}$ Session); Annual full-day discussion on Women's Human Rights (22 ${ }^{\text {nd }}$ Session); Panel Discussion on Access to Justice for Indigenous Peoples (18 September, $21^{\text {st }}$ Session).

16 See material in footnote 116 and 117.

17 See, for example, Freedman and Barker, 'The UN Human Rights Council keeps up its bad form on LGBT rights', The Conversation, 4 July 2014, available at: https://theconversation.com/un-human-rights-council-keeps-up-itsbad-form-on-lgbt-rights-28676 [last accessed 12 January 2017].

${ }^{18}$ For example, China has a reputation for obscuring the participation of NGOs. See, Sceats and Breslin, China and the International Human Rights System, Chatham House, October 2012, at 14.

${ }^{19}$ International Service for Human Rights, 'China Interrupts Moment Silence for Cao Shunli at the UN Human Rights Council', 20 March 2014, available at: http://www.ishr.ch/news/china-interrupts-moment-silence-caoshunli-un-human-rights-council [last accessed 3rd May 2016].

${ }^{20}$ For example, 'UN Watch (Point of order), General Debate Item: 8, 29th Meeting Human Rights Council', The UN Web TV, 24 September 2012, available at: http://webtv.un.org/watch/un-watch-point-of-order-generaldebate-item-8-29th-meeting-human-rights-council/1859598604001 [last accessed 3 May 2016]; Goodenough, 'NGO Asks UN Rights Council: Where Were You When Assad 'Starved and Murdered' 1,800 Palestinians?' CNSNews, 24 July 2014, available at: http://www.cnsnews.com/news/article/patrick-goodenough/ngo-asks-unrights-council-where-were-you-when-assad-starved-and [last accessed 3 May 2016].
} 
and how such politicisation represents backwards steps at the UN's principal human

rights body.

\section{FORUM FOR DIALOGUE}

In the run up to its establishment, it was envisaged that the Council would be a new forum for 'constructive international dialogue' on human rights. ${ }^{21}$ It would be a transparent, deliberative body, which embraced the principles of universality and impartiality. ${ }^{22}$ It would be objective in its work, and would foster cooperation between states to protect and promote human rights. ${ }^{23}$ The Council signalled a move away from 'naming and shaming' techniques that had dominated the Commission towards 'genuine dialogue' and inter-state cooperation. ${ }^{24}$ This focus on dialogue and cooperation, as a response to the failures of the Commission, is a step forward in terms of engaging states and promoting rights within a constructive atmosphere. In practice, however, politicisation of some if not many discussions has resulted in dialogues being hijacked by the tactics of states seeking to derail the Council's work.

Discussions in the run up to the creation of the Council placed weight on the need for 'peer review', ${ }^{25}$ dialogue, ${ }^{26}$ and accountability. The Secretary-General urged that the new Council was 'more accountable and more representative'. ${ }^{27}$ This echoed broader calls for reform across international organisations, where civil society actors were demanding increased participation and accountability. ${ }^{28}$ The Council's mandate reflects this ethos of legitimacy through the inclusivity invoked by the increased geographical representation of states, the founding principles, and the participation of non-state actors explored in Section 4.

The work of the Council is guided by its founding principles of 'universality, impartiality, objectivity and non-selectivity, constructive international dialogue and

\footnotetext{
${ }^{21}$ GA Res. 60/251, 'Human Rights Council', 15 March 2006, UN Doc. A/RES/60/251 at para 4.

22 Ibid, paras 12 and 4.

${ }^{23}$ Ibid, para 4 and para $5(f)$.

24 Ibid, preamble and para 12.

${ }^{25}$ General Assembly, 'Addendum to 'In Larger Freedom: Towards Development, Security and Human Rights for

All', Report of the Secretary General, 21 March 2005, UN Doc. A/59/2005/Add.1.

26 UNGA Official Records, '72 ${ }^{\text {nd }}$ Plenary Meeting', 15 March 2006, UN Doc. A/60/PV 72.

27 Speech of Secretary General Kofi Annan to the Commission on Human Rights, 'Reforming UN Human Rights Machinery', 7 April 2005, UN Press Release SG/SM/9808 HR/CN/1108.

28 See for example, Peters, 'Towards Transparency as a Global Norm' in Bianchi and Peters (eds), Transparency in International Law (2013) at 607; Fernández and Puyana, 'The Principles of Transparency and Inclusiveness as pillars of Global Governance' (2015) 11 BRICS Law Journal 7 at 21.
} 
cooperation'.29 The preparatory work to UN General Assembly Resolution 60/251, which created the Council, shows that negotiations centred on the role of dialogue in the new human rights body. ${ }^{30}$ The Council is mandated to '[s]erve as a forum for dialogue on thematic issues on all human rights' ${ }^{\prime 31}$ and throughout the mandate and the Institutional Building Package dialogue is at the core. ${ }^{32}$ The focus on transparency, participation and inclusiveness fosters a veil of legitimacy. ${ }^{33}$ Whilst this air of legitimacy is suggestive of a step forward, the reforms did not go far enough to combat politicisation.

Firstly, the founding principles do little to curb the behaviour of states. Those principles were created as guidelines for the body's work and as a method for combatting politicisation. They divide into two broad categories: principles that guide its work on human rights, and principles that guide its relationship to individual states. However, they are only guidelines. They are open-ended and somewhat ethereal, not precise requirements to which states must adhere. There is no definition of dialogue and cooperation within the Council mandate, and there is little consensus on the meaning of transparency and inclusiveness in international law. ${ }^{34}$ States can simply ignore or manipulate these principles, rather than adhere to them. Without clear requirements, states can hide behind the idea of dialogue, ${ }^{35}$ effectively doing little else other than talking about human rights. Dialogue becomes a positive outcome of itself rather than leading to greater human rights protection. As Lebovic and Voeten argue, 'states might acquire reputations as law-abiding global citizens by consistently participating in international institutions'. ${ }^{36}$ The principles are weak and subject to manipulation by states, which means they do little to enhance human rights. ${ }^{37}$

Secondly, the reformed membership of the Council does not address the political alliances that had given rise to politicisation at the Commission. The Council

\footnotetext{
29 GA Res. 60/251, para 4

30 UNGA Official Records, '72 ${ }^{\text {nd }}$ Plenary Meeting', 15 March 2006, UN Doc. A/60/PV 72. See also Ramcharan, The Law, Policy and Politics of the UN HRC (2015) at 2-3.

31 GA Res. 60/251, para. 5(b).

32 HRC Resolution 5/1, 'Institution-building of the United Nations Human Rights Council', 18 June 2007, UN Doc. A/HRC/RES/5/1 paras 3(b), 18(b), 21 and 29; GA Res. 60/251, preamble, paras 4, 5(b), 5(e), 5(f) and 12.

33 'A norm produced by the Human Rights Council, through a transparent procedure and inclusiveness, will always have higher legitimacy' in Fernández and Puyana, supra n 28 at 19

34 Peters, 'The Transparency of Global Governance' in Pazartzis et al., (eds), Reconceptualising the Rule of Law in Global Governance, Resources, Investment \& Trade (2016); Fernández and Puyana, supra n 28.

35 Ghanea, 'United Nations Commission for Human Rights to United Nations Human Rights Council: One Step

Forwards or Two Steps Sideways?' (2006) 55(3) International and Comparative Law Quarterly 695 at 704.

36 Lebovic and Voeten, 'The Politics of Shame: The Condemnation of Country Human Rights Practices in the UNCHR' (2006) International Studies Quarterly 861 at 870.

${ }^{37}$ For example, at the 16th Special Session on the situation in the Syrian Arab Republic, the first Special Session on Syria, Iran challenged the calling of the Special Session and raised concerns about 'selectivity' and double standards. The delegate for Syria accused the Council of 'selectivity', and then proceeded to raise Israel's human rights abuses. See, Human Rights Council Webcasts, 16th Special Session on the Situation of Human Rights in the Syrian Arab Republic, 29 April 2011, statement of Iran / statement of Syria.
} 
is constituted of 47 member states, elected from regional groups. ${ }^{38}$ There are 13 seats for states from the Group of African States, 13 seats for the Group of Asian States, 6 seats for the Group of Eastern European States, 8 for the Group of Latin American and Caribbean States, and 7 for the Group of Western European and other States. ${ }^{39}$ Resolution 60/251 focuses on UN regional groups in apportioning seats to members in an attempt to achieve 'equitable geographical distribution', 40 but it serves to reinforce the strong political allegiances within groups. The election process for membership to the Council is just one example of the strength of these regional groups. Often regional groups present only one candidate for each available seat. Without genuine competition, the human rights records of candidate states are not sufficiently assessed, potentially opening membership to states with poor records. The seat distribution also ignores alliances between groups, as had occurred at the Commission, which often results in what Schrijver identifies as 'the Rest against the West'. ${ }^{41}$

Other powerful political coalitions also operate within the Council. ${ }^{42}$ Nongeographically-based alliances occur among both developed and developing states. ${ }^{43}$ The Non-Aligned Movement (NAM) and the G-77, which were the traditional Global South political blocs during the Cold War, ${ }^{44}$ remain loosely allied at the Council but largely have given way to the OIC, the G20+, the BRICS - composed of Brazil, Russia, India, China and South Africa - and the Like-Minded Group of Developing Countries (LMG) in terms of where the political power is vested. As Freedman has noted, these blocs have members from different regional groups, and they almost always have strong representation at the Council. ${ }^{45}$ OIC dominance of proceedings, the European Union's passivity, ${ }^{46}$ and the undermining actions of the LMG have negatively impacted upon the Council's work. ${ }^{47}$ Of those, the OIC and the LMG have been the most active in terms of politicising the Council to achieve objectives largely or fully unrelated to human rights. The alliances generally have had a negative effect on the Council's ability to take action. ${ }^{48}$ States holding membership of more than one group, especially those with large membership, have many allies to protect them

\footnotetext{
38 GA Res. 60/251, para 7.

39 Ibid.

${ }^{40}$ Ibid.

${ }^{41}$ Schrijver, supra $\mathrm{n} 8$ at 812 .

$42 \mathrm{Nicol}$, 'Interregional Co-ordination Within the United Nations: The Role of the Commonwealth' in Andemicael (ed), Regionalism and the United Nations (1979) at 102.

43 Weiss, What's Wrong with the United Nations and How to Fix It (2008) at 50.

${ }^{44}$ Berger, 'After the Third World? History, Destiny and the Fate of Third Worldism' (2004) 25 Third World

Quarterly 1 at 13.

45 Freedman, The United Nations Human Rights Council: a critique and early assessment (2013) Chapter 6.

${ }^{46}$ Article 34(1) of Treaty on European Union states that EU Member States 'shall coordinate their action in international organisations and ... shall uphold the common positions in such forums'. Treaty on European Union

[2007] O] C 115/01. See, Smith, 'Speaking with One Voice? European Union Co-ordination on Human Rights Issues at the United Nations' (2006) 44 Journal of Common Market Studies 113.

47 Freedman, supra n 45 at Chapters 6 and 8.

$48 \mathrm{Cf}$. Hug \& Lukacs, 'Preferences or blocs? Voting in the United Nations Human Rights Council' (2014) 9 The

Review of International Organizations 83-106.
} 
from action. States use repeated statements, supporting statements, irrelevant statements, and statements of alliance and allegiance to reduce the utility of dialogues at the Council. ${ }^{49}$

The Council's politicisation is attributable both to its membership and its structure. Understanding the Council as a forum for dialogue allows for an air of legitimacy - it appears to foster inclusion, participation and transparency - and yet this structural form does little to prevent politicisation. In 2006, Abraham argued that overcoming politicisation at the Council would be difficult because it relates to the 'culture and practices adopted by member states'. ${ }^{50}$ This means that it is not something that can be rectified by changes to 'working methods' alone. She suggested that the Council would need to adopt methods that did not reinforce the regional structure, ${ }^{51}$ and it seems clear 10 years later that the focus on regionalism in the Council's constituent instrument continues the politicisation prevalent in the former Commission through the dominance of regional groups and political blocs.

\section{COUNTRY-SPECIFIC SITUATIONS}

A vital aspect of the Council's work is scrutiny of country situations within which grave or ongoing violations occur. Such scrutiny seeks to uncover and share information about human rights abuses as well as to devise strategies and to place pressures on states to uphold their human rights obligations. Yet it is in this area that the most obvious and pernicious politicisation occurs at the Council. There are three politicised ways in which the Council deals with country situations. It excessively scrutinises some countries, altogether ignores other abusers, and shields yet others from action taken against abusive regimes. ${ }^{52}$

An early warning of the Council's politicisation (which continued some of the practices that had undermined the Commission) was seen when it created the permanent agenda that is followed at each regular session. In direct contradiction of the founding principles of non-selectivity and universality, one country-specific situation alone is singled out to be discussed at every regular Council session.

\footnotetext{
${ }^{49}$ At an Interactive Dialogue with the Commission of Inquiry on Libya on 19 September 2011, states from the Arab Group repeatedly welcomed and congratulated the NTC in Libya. See, Human Rights Council News Archive, 'Human Rights Council holds interactive dialogue with Commission of Inquiry on Libya', 19 September 2011. An example of an irrelevant statement arose at the $4^{\text {th }}$ Special Session on the Situation in Darfur on $12^{\text {th }}$ December 2006, when Palestine drew attention to the situation in Israel. See, Freedman, supra n 45 at 223.

50 Abraham, A New Chapter for Human Rights: A Handbook on Issues of Transition from the Commission on Human Rights to the Human Rights Council, International Service for Human Rights, Friedrich Ebert Stiftung, 2006 at 28.

51 Ibid.

${ }^{52}$ Freedman, supra n 45 at section 6.3.
} 
Agenda Item 7 mandates that the human rights situation in 'Palestine and other occupied Arab territories' is discussed under its own agenda item rather than in the general item on country-situations. ${ }^{53}$ Politicisation in this regard repeated what had occurred at the Commission in relation to Israel, and demonstrated that not enough had been done to ensure that the Council was anything different from the Commission. Excessive scrutiny of one country-situation through a standing agenda item is clearly selective, particularly given the persistence of other long-standing and equally or more grave crisis regions or situations. That agenda item was proposed and supported by OIC members and their allies, and the bloc's dominance enabled it to secure the item on the permanent agenda. Clearly, the inclusion of Item 7 related to OIC political objectives despite obviously violating the body's founding principles. 54

Singling out particular countries for excessive and disproportionate focus has been a recurring theme throughout the Council's existence. Israel is not the only example of this type of politicisation in relation to country-specific situations. Throughout the Council's decade-long existence certain states find themselves firmly within the body's spotlight. Severe human rights violations coupled with their 'pariah' status that means they lack sufficient allies at the Council to shield them from disproportionate scrutiny. While those countries do require attention, human rights are not zero-sum - the Council only has a limited and finite amount of time for discussing and taking action on a broad range of situations, and therefore excessive scrutiny of some states detracts from its ability to take needed action elsewhere. As such, its excessive focus on one country is a tactic used frequently to deflect attention away from other, equally grave, country-specific situations.

Israel $^{55}$ and Syria ${ }^{56}$ have at different times found themselves in the category of having excess scrutiny as compared with other similar or worse situations elsewhere such as Russia's incursions into Georgia, South Ossetia, and the Crimea, Turkey's occupation of Northern Cyprus, the uprisings in Egypt during the Arab Spring, and many other situations that have been all-but ignored by the Council. Those conflicts have killed, injured, displaced, and otherwise seriously harmed large numbers of civilians, and of course are deserving of attention within the Council, and more broadly within the UN. However, the disproportionate attention given to those two conflicts as compared with other, similar situations ${ }^{57}$ that have claimed many more victims, at least in part is owing to politicisation of the Council.

\footnotetext{
53 HRC Res. 5/1, Part V (B).

54 See Freedman, supra $\mathrm{n} 45$ at 81-83.

55 See, for example, Freedman, supra n 10 at 209-251.

56 See footnotes 116 and 117.

${ }^{57}$ As pointed out by then-Secretary General Kofi Annan: UN Press Release, 'Secretary General in Message to

Human Rights Council Cautions against Focusing on Middle East at expense of Darfur, Other Grave Crises', 29

November 2006, UN Doc. SG/SM/10769-HR/4907. See, also, Speech by Kofi Annan, 8 December 2006, in which
} 
It is no coincidence that those two countries feature highly on the political agendas of many OIC member states. OIC members dominate at the Council. They are the drivers behind the excessive focus on Israel and on Syria. In relation to Syria, which is discussed in greater detail in Section 5, OIC objectives vary between different member states depending on religious, cultural, geographic, economic and military interest in addressing the conflict. In relation to Israel, their objectives include political, religious, cultural and regional ties with the Palestinians and with affected neighbouring states. Crucially, those countries also use Israel to divert attention away from systemic violations within influential OIC members such as Pakistan, Algeria and Egypt. Irrelevant statements, such as during General Debates, when OIC members draw attention to the situation in Palestine, are still used to divert attention away from human rights abusers. The problem with these sorts of repeat or irrelevant statements is that they waste time and they influence the perception of a situation.

Another reason that some countries overtly politicise the conflicts in Israel and in Syria is because of connections with the US and Russia respectively. Israel is seen as the US foothold in the Middle East. That relationship encourages anti-US states, such as Cuba, China, Venezuela, and Russia, to use Israel as a way of attacking US hegemony and interference. More recently, Russia's involvement in Syria has received particularly negative reactions from a broad spectrum of states that are not naturally allied with one another, many of which appear concerned about recent hegemonic-aspirations from that country. The Cold War might long be over, but the practices learnt during those times still persist.

It was hoped - perhaps even expected - that the Council would avoid its predecessor's lack of even-handedness in country-specific scrutiny. Indeed, supposed 'safeguards' - that is the founding principles - were built into Resolution $60 / 251$ to achieve that aim. ${ }^{58}$ Yet these principles are altogether ignored when it comes to some country situations. The disproportionate attention given to some states can be compared with the failures to address grave violations in countries that yield political power in terms of alliances with many Council members. Such countries include China, Russia and Egypt, all of which are known grave abusers and where crises and ongoing abuses have altogether been ignored by the Council. When looking at the Council's composition, it is clear why China's abuses in the leadup to the Beijing Olympic Games (2008), ${ }^{59}$ Russia's violations during incursions into

he stated 'we must realize the promise of the Human Rights Council which so far has clearly not justified the hopes that so many of us placed in it'.

${ }^{58}$ See material in footnotes $25-33$ above.

59 Freedman, supra n 5 at 88-89. 
Georgia and South Ossetia (2008), ${ }^{60}$ and the grave abuses during Egypt's revolution have not been discussed at the body. ${ }^{61}$ Those countries have strong alliances across regional groups and political blocs that dominate the Council, which means they are shielded from scrutiny and action. ${ }^{62}$

In between the pariah States and the most politically-powerful countries are the very many others that have allies but cannot be protected fully from some attention when such attention is merited. Those countries rely on a different form of politicisation when the Council shines a spotlight onto grave abuses within their territories. States like Sudan and Sri Lanka have received proportionate attention for violations that may amount to genocides within their countries, but their allies have politicised discussions by shielding them from significant criticism or action. Instead, those allies have deflected the focus onto human rights abuses committed by nonstate actors within those countries or have called upon the international community to support abuser-governments through capacity-building and technical assistance despite clear evidence that those governments have been behind the grave abuses being perpetrated.

Sudan is a member both of the African Group and of the OIC, which are respectively the largest regional group and largest political bloc at the Council. Sudan therefore received significant support from allied states, ${ }^{63}$ but that support did not fully shield it from attention. The weight of evidence meant that violations could not be swept under the carpet and that Darfur could not be kept off the Council's agenda. Instead, Sudan's allies ensured that the Council apportioned blame on other actors for abuses in Darfur and called for capacity building and assistance to Sudan's government. ${ }^{64}$ Sri Lanka, which is a member of the Asian Group and has significant allies within that region as well as in key political blocs, relied upon appealing to the LMG, OIC and NAM on issues of sovereignty as a method for convincing those States to block action by the Council. As will be explored in Section 5, not only was that tactic successful in shielding Sri Lanka from criticism but it also undermined the Council's ability later to take similar, needed action on other countries.

The main problem with states shifting the blame onto other actors is that it is used as a tactic to deflect attention away from state-sponsored abuses. Calls to support Sudan and the Sri Lankan government were a method for shielding those states. They did not acknowledge, let alone deal with, the government's responsibility for those violations. Instead, they provided a smokescreen that

60 See also Chechnya in Freedman, supra n 5 at 57-59.

61 ibid 65.

62 ibid Chapter 9.

63 Freedman, supra n 45 at 244.

64 Ibid at 239, 243, 249. 
allowed Sudan to continue to collude in the atrocities within Darfur and that allowed Sri Lanka to escape accountability for its grave human rights abuses. Although claims of lack of capacity may be true in fragile states, they are increasingly being used by many states that have the resources but lack the political will to implement rights. Those calls for assistance are taken up by states' political and regional allies. It stops the Council taking meaningful action on grave abuses within those states. Instead, pressure is placed on the UN and aid agencies to support governments that are actually perpetrating gross and systemic violations.

\section{PARTICIPATION OF NON-GOVERNMENTAL ORGANISATIONS}

The webpages of the Council tell a story of the participation and inclusion of NGOs. ${ }^{65}$ Practical Guides and Handbooks are available to help NGOs understand the work of the Council, its processes, and the ways in which they can participate. ${ }^{66}$ At the Council, NGOs can attend and observe proceedings, submit written statements and make oral interventions, as well as organise 'parallel' events alongside Council sessions. ${ }^{67}$ The Council made participation for NGOs even easier by introducing video messages for oral submissions, so NGOs can send in their comments without paying for a trip to Geneva. ${ }^{68}$ There has been an increase in the number of NGOs participating at the Council. At the first session in 2006, 154 NGOs participated, ${ }^{69}$ and in 2014 at the $27^{\text {th }}$ Council Session, representatives from approximately 279 NGOs participated. ${ }^{70}$ But the story from the NGO community is not so rosy: NGOs are denied accreditation, ${ }^{71}$ ignored within Council sessions, ${ }^{72}$ and have their participation challenged by states. ${ }^{73}$ NGO participation is another area where in

65 United Nations Human Rights Council, 'NGO and NHRI Information' available at: http://www.ohchr.org/EN/HRBodies/HRC/Pages/NgoNhriInfo.aspx [last accessed 3rd May 2016].

66 United Nations Human Rights Council, 'A Practical Guide for NGO Participants' Geneva, 2013; Office of the High Commissioner for Human Rights, 'Working with the United Nations Human Rights Programme: A Handbook for Civil Society' Geneva, 2008.

67 GA Res. 60/251, para 11.

68 Office of the High Commissioner for Human Rights, 'NGO Participation in the Human Rights Council' available at: http://www.ohchr.org/EN/HRBodies/HRC/Pages/NgoParticipation.aspx [last accessed 3rd May 2016].

69 The number of NGOs that were registered as attending in the Report for the $1^{\text {st }}$ Council Session (19-30 June 2006). UNHRC, 'Report of the Human Rights Council' 2006 UN Doc. A/61/53, 86-88.

70 The number of NGOs that were registered as attending in the Report for the $27^{\text {th }}$ Council Session ( 8 to 26 September 2014). UNHRC, 'Report of the Human Rights Council on its twenty-seventh session', 22 December 2014, UN Doc. A/HRC/27/2, 156-160.

${ }^{71}$ In February 2016, The NGO Committee voted to close the application of the Khmers Kampuchea-Krom Federation. International Service for Human Rights, 'UN Committee on NGOs: Don't deny NGO the right to speak', 29 January 2016, available at: http://www.ishr.ch/news/un-committee-ngos-dont-deny-ngo-rightspeak\#sthash.EyKaYByl.dpuf [last accessed 3 May 2016]

72 See Freedman, supra $\mathrm{n} 5$ at xiii, xiv.

73 States will raise points of order to interrupt NGO statements. For a detailed discussion on Egypt's practice see, Landolt, 'Externalising Human Rights: From Commission to Council, the UPR and Egypt' (2013) 14 Human Rights Review 107-129. 
theory there is progress, but in practice, the politicisation of NGO accreditation and proceedings has threatened their inclusion at the Council.

The UN Charter facilitates consultation with NGOs. ${ }^{74}$ The Economic and Social Council (ECOSOC) has outlined the terms for participation and divided NGOs into three types of consultative status: General, Special and Roster. General consultative status means 'organizations that are concerned with most of the activities of the Council' and Special consultative status means 'organizations that have a special competence in, and are concerned specifically with, only a few of the fields of activity covered by the Council'. ${ }^{75}$ The Roster is a list of NGOs that are considered to be useful on occasions. Consultative status allows for written and oral submissions. This process of applying for consultative status was subsequently adopted by the Council. ${ }^{76}$

The UN Committee on Non-governmental organisations (a subsidiary body of ECOSOC) comprises 19 member states that recommend NGOs for consultative status. Responding to criticisms of a western bias within the Committee, membership is based on equitable geographical distribution. ${ }^{77}$ There are 5 members from African States, 4 members from Asian States, 2 members from Eastern European States, 4 members from Latin American and Caribbean States, and 4 members from Western European and other States. There are a number of factors that should guide the Committee in its work. ${ }^{78}$ For example, NGOs should have a representative structure, possess accountability mechanisms, and they should have an established headquarters. ${ }^{79}$ The Committee should also have regard to the encouragement of representation from developing states and those states that have transitional economies. ${ }^{80}$ The Committee has four options: to recommend the NGO for accreditation, defer an application by asking a question of the NGO that will stall their application, vote for a withdrawal of the application, or close an application where the NGO is unresponsive.

Despite these principles that should guide the questions from the Committee, states are still able to ask inappropriate questions of NGOs, thus stalling their

\footnotetext{
${ }^{74}$ Article 71 states that ECOSOC 'may make suitable arrangements for consultation with non-governmental organisations' United Nations Charter 1945, 1 UNTS XVI.

75 ECOSOC Resolution 1996/31, 'Consultative relationship between the United Nations and non-governmental organizations', 25 July 1996, UN Doc. E/Res/1996/31, paras 22 and 23.

76 GA Res. 60/251, para 11.

77 Otto, 'NGOs in the UN System: The Emerging Role of International Civil Society' (1996) 18(1) Human Rights Quarterly 107 at 115.

78 ECOSOC Resolution 1996/31, Part I, paras 1-17.

79 Ibid, paras 10 and 12

${ }^{80}$ Ibid, para 6 and 7.
} 
application for accreditation. ${ }^{81}$ In some cases, NGOs are asked questions repeatedly. For example, at the Committee meeting in June 2016, the International Dalit Solidarity Network was considered for the 18th time. Its application had been stalled in the past by questions from India. In total, it has received 77 questions from India alone. ${ }^{82}$ NGOs with limited budgets are prevented from participating due to the indirect costs of reapplying. The short deadlines to apply for accreditation and the budgetary constraints faced by NGOs are just two of a host of procedural reasons why access or participation at the UN is curtailed for NGOs. ${ }^{83}$

The mandate of the Council explicitly provides for the participation of NGOs. The Council mandate extols the virtues of NGOs in the protection of human rights as it '[acknowledges] that non-governmental organizations play an important role at the national, regional and international levels, in the promotion and protection of human rights'. ${ }^{84}$ The involvement of NGOs is further buttressed through the procedures and processes set out in the UNHRC Institution-Building Package. This states that participation should include 'all relevant stakeholders, including non-governmental organizations and national human rights institutions' ${ }^{\prime} 85$

However, there are limitations placed on NGO participation at Council sessions. The length of submissions are dictated by the nature of the status granted to the NGO: General consultative status allows 2,000 word submissions and special consultative status allows 1,500 words to bodies like the Council. ${ }^{86}$ The Council has working modalities that outline how an NGO should participate, often restricting the types of comments that can be made depending on the type of session. ${ }^{87}$ Limited time is given for NGO oral submissions. Usually NGOs have two or three minutes depending on the type of proceeding and even this can be reduced if Member States overrun in their submissions. Moreover, there have been recent attempts to stop NGO participation in the Council sessions. There are accusations that some states

\footnotetext{
${ }^{81}$ For example, China repeatedly asks NGOs to state their position on Tibet or Taiwan. See, Evans, International Service for Human Rights: A Practical Guide to the UN Committee on NGOs, International Service for Human Rights, Geneva and London, 2015 at 48-49.

82 International Service for Human Rights, 'Political interests continue to distort the decisions of the NGO

Committee, but this time the world is watching', 14 June 2016, available at: http://www.ishr.ch/news/politicalinterests-continue-distort-decisions-ngo-committee-time-world-watching-0 [last accessed 5 December 2016].

${ }^{83}$ International Service for Human Rights, 'Accreditation procedure threatens to undercut civil society participation at UN meeting', 24 April 2013, updated 1 May 2013, available at:

http://www.ishr.ch/news/accreditation-procedure-threatens-undercut-civil-society-participation-un-meeting [last accessed 23 April 2014].

${ }^{84}$ GA Res. 60/251, preamble.

85 HRC Res. $5 / 1$, para $m$.

${ }^{86}$ ECOSOC Resolution 1996/31, para 31(d) and (e) and 37(e).

87 See for example, 'A Practical Guide for NGO Participants' supra n 66.

For Interactive Dialogues on Special Procedures, presentations should 'relate to reports under consideration or to the [Special Procedures] mandate', similarly for Interactive Dialogues with High Commissioner for Human Rights, NGOs should relate their presentations to the reports, updates or High Commissioner's mandate. For General Debates, the NGO should discuss the relevant Agenda Item that is under consideration.
} 
'pressure and intimidate' employees at the Council to allow certain NGOs to speak ${ }^{88}$ and states use points of order to hinder or prevent NGO participation. ${ }^{89}$

The mechanism of Universal Periodic Review (UPR) has facilitated new ways for NGOs to participate at the Council. ${ }^{90}$ UPR is the review of all states' human rights record. Three formal reports are submitted for each state, one of which is a compilation of stakeholder submissions. This stakeholder submission allows for the information on human rights practices in states and comments from NGOs to form a part of the formal reporting process. The review process is in two parts: the first is a working group session that NGOs are allowed to observe but not participate, and the second is a plenary session where NGOs can make 'general comments'. ${ }^{91}$

However, within UPR the extent of NGO participation is limited. ${ }^{92}$ Although they are present at the first discursive stages and participate in the plenary session, ${ }^{93}$ there is no formal role for NGOs in the Working Group stage. ${ }^{94}$ The actual scope for NGO influence can be restricted by state behaviour, as the state that is under review is able to determine to which, if any, comments and questions from states and NGOs it will respond. This restricts the influence of states and NGOs alike. In the discussions on the creation of UPR, states in the African Group had tried to prevent NGO participation. ${ }^{95}$ This was not successful, but liberal states' challenges to information provided by NGOs, ${ }^{96}$ requests for NGO comments to be removed from the official records, ${ }^{97}$ and interruptions during their statements, ${ }^{98}$ show that attempts are made to undermine NGO participation in the plenary sessions.

\footnotetext{
88 Landolt, supra $\mathrm{n} 73$ at 118. A recent example is the abuse suffered by Florian Irminger, the Head of Advocacy at Human Rights House Network, who received death threats from a diplomat from the Russian Federation. See, Human Rights House Network, 'UN Secretary General seeks to address threats and reprisals', 13 June 2016, available at: http://humanrightshouse.org/Articles/21686.html [last accessed 5 December 2016].

${ }^{89}$ For example, China used a 'point of order' to prevent ISHR holding a minute's silence for the human rights defender, Cao Shunli. The President of the Council called for a vote, but only 13 states voted for allowing ISHR to continue. See supra $\mathrm{n} 19$.

${ }^{90}$ Landolt and Woo, 'NGOs invite attention: from the UN Commission on Human Rights to the Human Rights Council' (2016) Journal of Human Rights 1 at 6.

91 HRC Res. 5/1, para 31.

92 NGOs are entitled to observe the review in the room, and may conduct parallel events, but they are only entitled to take the floor later during the consideration and adoption of reports in the Council plenary.

${ }_{93}$ The Institutional Building Package provides that 'relevant stakeholders will have the opportunity to make general comments'. HRC Res. 5/1, para 31.

${ }_{94}$ Which has been criticised by ISHR. See, Leather and McEvoy, 'Towards a UPR which is accessible, strong, effective and protective' International Service for Human Rights, 2 June 2016, available at: http://www.ishr.ch/news/towards-upr-which-accessible-strong-effective-and-protective [last accessed 12 January 2017].

95 Landolt supra $\mathrm{n} 73$ at 117

96 Landolt and Woo, supra $\mathrm{n} 90$ at 16.

97 Emma Hickey gives the examples of Cuba and Egypt asking for NGO comments to be removed from the official records. See, Hickey, 'The UN's Universal Periodifc Review: Is it Adding Value and Improving the Human Rights Siutation on the Grounf? A critical evaluation of the First Cycle and Recommendations for Reform' (2013) 7(4) International Constitutional Law Journal 1 at 19.

98 Landolt discusses the example of Egypt, who interrupted the statement of the Cairo Institute for Human Rights Studies. See Landolt supra n 73 at 118.
} 
As noted, the Council has explicitly ensured a participatory role for NGOs. The introduction of video messaging, the space for organising parallel sessions, and the explicit role of NGOs in submissions to UPR is progress towards a more inclusive dialogue on human rights. Nevertheless, the politicisation at the UN Committee for NGOs and the Council means that the participation of NGOs and their accreditation is subject to the political interests of states.

\section{SPECIAL SESSIONS}

The Council has two new mechanisms that directly address criticisms of the Commission and that aim to assist the Council with fulfilling its mandate: UPR and Special Sessions. Both mechanisms enhance the Council's ability universally to fulfil its mandate and to respond to serious situations in a timely manner. But both have been politicised in much the same way as the Council has been. While much has been written about UPR, ${ }^{99}$ there has been little scrutiny of Special Sessions. In this section, we shall look at Special Sessions to demonstrate how politicisation has manifested within that mechanism and the impact it has had on the Council's work.

Special Sessions are aimed at fulfilling the body's protection mandate and enabling the Council to respond swiftly to grave and escalating situations that occur outside of the time period allocated for regular sessions. A main failing of the Commission was that its annual session allowed neither the time nor the dexterity to deal with crisis situations. Special Sessions provide the ability to discuss grave or crisis situations inter-sessionally and at short notice. They are separate sessions and, because of this, convening a Special Session enables a quick and focused response without using time and resources allocated for other human rights matters.

The Council is given the ability 'to hold special sessions when needed', ${ }^{100}$ but is not mandated to convene them. Rather the mechanism is left open for the Council to interpret and utilise as it sees fit. Special Sessions can be held at the request of one member, but only if one third of Council members support holding the session. ${ }^{101}$ It was hoped that this requirement would discourage the use of Special

${ }^{99}$ For discussion of UPR see Freedman, supra n 45 at 9.1; Freeman, 'New Mechanisms of the UN Human Rights Council' (2011) 29(3) Netherlands Quarterly of Human Rights 289; Abebe, 'Of Shaming and Bargaining: African States and the Universal Periodic Review of the United Nations Human Rights Council' (2009) 9 Human Rights Law Review 1.

100 GA Res. 60/251, para 10.

101 Ibid. 
Sessions as a political tool, whilst still allowing them to be convened quickly and efficiently where required. Of course, and as we shall see, that was a rather naïve and idealistic expectation.

It was envisaged, particularly by the Global North, that sessions would focus on thematic issues; and although that has occurred occasionally - for example regarding the global financial crisis, ${ }^{102}$ the world food crisis ${ }^{103}$ or transnational terrorism committed by ISIS ${ }^{104}$ - the mechanism's potential in that regard has not been exploited. Failures to convene a Special Session on irregular migration when crises have occurred in relation to deaths of migrants seeking to reach Europe by sea, bondage of workers in Qatar during the building of infrastructure for the 2022 FIFA World Cup, or other similar crisis situations that have occurred, demonstrate that the mechanism is not being used fully for the purposes that its creators intended. Instead, the vast overwhelming majority of the Council's 26 Special Sessions have been convened about country-specific situations. While such sessions are also needed it is only half of the mechanism's mandate and potential.

OHCHR staff involved in creating the Council ${ }^{105}$ foresaw and forewarned Global North states that the mechanism would likely be used instead to target particular country-specific situations for politicised reasons and that it was likely that the same selectivity and bias that occurred at the Commission would plague the Special Session mechanism. During the Council's early years it swiftly became apparent that the warnings ought to have been heeded. 5 of the Council's first 12 Special Sessions focused on Israel and the Occupied Territories. While that is a grave situation, and while crises arose during that time, the disproportionate attention can be compared with the sole Special Session on Darfur where a genocide was being perpetrated, ${ }^{106}$ the sole Special Session on the Congo where more than 6 million people had been killed at that time, and the failure to hold any Special Sessions on countries with ongoing grave situations of repression, such as North Korea and Zimbabwe, or of occupation, such as Morocco and Western Sahara or Turkey and Northern Cyprus. Schrijver insists that when the Palestinian plight is considered, Western observations that the Council excessively focuses on Israel is questionable. ${ }^{107}$ However, owing to

$10210^{\text {th }}$ Special Session, 'The impact of the global economic and financial crisis on the universal realisation and effective enjoyment of human rights' (20 th February 2009).

$1037^{\text {th }}$ Special Session, 'The negative impact of the worsening world food' (22 nd May 2008).

$10422^{\text {nd }}$ Special Session, 'The Human Rights Council on the human rights situation in Iraq in light of abuses committed by the Islamic State in Iraq and the Levant and associated groups' (1 ${ }^{\text {st }}$ September 2014).

${ }^{105}$ Interviews conducted by the author on the basis of anonymity 2012-2015 (funded by the British Academy).

106 The situation has been identified by many as a genocide, see for example Sanders, 'Is the Darfur bloodshed genocide? Opinions differ', LA Times, 4 May 2009. In July 2010, the International Criminal Court issued a second arrest warrant for Sudan's President, Omar Al-Bashir, adding genocide to its original list of charges for crimes allegedly committed in Darfur: International Criminal Court Second Warrant of Arrest for Omar Hassan Ahmad Al Bashir, in the case of The Prosecutor v. Omar Hassan Ahmad Al Bashir ('Omar Al Bashir'), 12 July 2010, ICC02/05-01/09.

107 Schrijver, supra n 8 at 820. 
similar, if not worse, abuses ongoing elsewhere, Gaer argues that convening three Special Sessions on Israel in the Council's first six months raised serious concerns about the new body and its members. ${ }^{108}$

The mechanism has similarly been politicised in the ways that it has and has not been used to respond to the Arab Spring Uprisings. In 2011 and 2012 there were 4 Special Sessions on Syria, a country expelled by the Arab League and that no longer is protected by most of its former political allies in the MENA region. ${ }^{109}$ The situation in Syria and how to address the grave crisis has divided opinion within the OIC, so that political bloc did not vote en masse to block scrutiny of its member state. ${ }^{110}$ Selectivity, and disproportionate scrutiny of Syria, ${ }^{111}$ can be compared with the failure to convene a Special Session on Bahrain, Egypt, Tunisia or Yemen, or even a thematic session on the Arab Spring uprisings generally.

Politicisation through bias, disproportionate attention and selectivity was always a risk, but the methods for convening a session increase the likelihood of it occurring. Requiring the support of one third of Council members empowers dominant groups and alliances to use this mechanism to achieve political aims. The larger the group, the more easily the one-third threshold is achieved. Once again, this has manifested itself in the mechanism's use for selective, biased and politicised purposes, such as the vastly disproportionate attention being devoted to Israel and Syria, whilst other similar or more egregious situations have been given little or no attention. It is only when a state lacks political allies that the spotlight of so many Special Sessions can be shone to illuminate the human rights abuses occurring whilst also deflecting attention away from other similar situations elsewhere.

A different form of the politicisation of Special Sessions is the way in which countries are shielded from scrutiny at sessions that were convened to scrutinise human rights abuses in those very same states. That tactic has been deployed most notably in the sessions about Darfur and about Sri Lanka. In both of those sessions, allies of those countries used bloc and group politicisation tactics to ensure that the scrutiny and action intended for those states were diverted to other actors.

\footnotetext{
108 Gaer, 'A Voice not an echo: universal periodic review and the UN treaty body system' (2007) 7 Human Rights Law Review 109, at 135-136.

${ }^{109}$ For example, Libya supported the $18^{\text {th }}$ Special Session on Syria and spoke out about the violations taking place in Syria. HRC Resolution S-18/1 (2 December 2011) UN Doc. A/HRC/RES/S-18/1.

110 Whereas the resolutions on Sudan were voted against (HRC Resolution 15/27 (1 October 2010) UN Doc. A/HRC/RES/15/27) by April 2012, the resolutions on Syria (HRC Resolution 19/1 (10 April 2012) UN Doc. A/HRC/RES/19/1; HRC Resolution 19/22 (10 April 2012) UN Doc. A/HRC/RES/19/22) and Iran (HRC Resolution 19/120 (3 April 2012) UN Doc. A/HRC/RES/19/12) were voted for or states abstained.

111 Three weeks before the $18^{\text {th }}$ Session, and two months before Syria was reviewed under the Universal Periodic Review, a second Special Session on Syria was held.
} 
In terms of the Special Session on Darfur, states allied with Sudan ensured that attention was focused on non-state actors' role in the conflict and that support, capacity-building and technical assistance was promised to Sudan's government. While those states had failed to shield Sudan from the Council's attention, both in regular and special sessions, they diverted the spotlight away from the government's abuses and shifted the narrative to one of the government being unable to prevent violations. $^{112}$ That narrative, of course, is at odds with the vast majority of information and evidence available at that time about the atrocities in Darfur, ${ }^{113}$ and demonstrates the gross politicisation that can and does take place within an intergovernmental forum owing to politics being able to supersede the body's aims and mandate.

The EU called for a Special Session on Sri Lanka in May 2009, a week after the defeat of the Liberation Tigers of Tamil Eelam (LTTE) by government forces and the resulting fears about massacres etc. The government of Sri Lanka issued a joint communiqué together with the UN Secretary-General in which Sri Lanka reiterated its commitment to protecting and promoting human rights and the UN SecretaryGeneral emphasised the importance of an accountability process. Not only did the Special Session fail to enforce accountability, the outcome was a 'deeply flawed'114 resolution ${ }^{115}$ that put forward the government's version of events, praised state forces, and pointed the finger only at abuses committed by the LTTE. The resolution passed with 29 votes in favour, 12 against, and 6 abstentions. Most states supporting Sri Lanka were its allies from the Asian Group or the NAM, who sought to shield it from Council action. Human Rights Watch said that Brazil, Cuba, India, and Pakistan led efforts to block a stronger resolution focusing on government abuses. Even more problematically, the resolution sought to entrench the position held by many Global South states that the Council cannot interfere with the affairs within a state's domestic jurisdiction even though human rights violations are not understood in international law to be part of inherently domestic matters and indeed it is anathema to international human rights law to claim that abuses are exclusively part of the internal affairs of a sovereign country. ${ }^{116}$

The option to convene Special Sessions on human rights emergencies was an attempt to address the failure of the Commission to respond to such situations.

\footnotetext{
112 For detailed analysis of the Council's failures to address the situation in Darfur, and the reasons for those failures, see Freedman, supra n 45 at Chapter 8.

113 For in-depth discussion and analysis of those abuses see: Totten, Genocide in Darfur: Investigating the Atrocities in the Sudan (2006); Hassan and Ray, Darfur and the Crisis on Governance in Sudan (2009).

114 Human Rights Watch, 'Sri Lanka: UN Human Rights Council Fails Victims', Human Rights Watch, 27 May 2009, available at: http://www.hrw.org/news/2009/05/27/sri-lanka-un-rights-council-fails-victims [last accessed 12 January 2017].

115 HRC Resolution S-11/1, 'Assistance to Sri Lanka in the promotion and protection of human rights', 27 May 2009.

116 Ibid, preamble.
} 
Special Sessions direct time and resources to addressing particular grave or crisis human rights situations. Such an opportunity is a step forward in the protection of human rights. Yet, the process of convening a Special Session and the sessions themselves have been politicised.

\section{CONCLUSION}

A decade on, the UN Human Rights Council can be praised for its achievements in terms of protection and promotion of human rights, but that ought not overshadow the criticisms that must be made and addressed. Steps forward - such as the introduction of fundamental principles guiding the work of the Council, the greater role for NGOs, and the option of Special Sessions - have been accompanied by simultaneous steps backward. Problematically, those steps backwards, which we have detailed in this article, are ones that mirror the same problems as beset its predecessor, the Commission on Human Rights, demonstrating that the failings at that body have continued at this new institution. Despite emphasis on institutional reform through tinkering with and adjusting specific aspects of the body, the Council has been undermined by states using its mechanisms, discussions and sessions to advance unrelated political objectives. Politicisation is widespread at the Council, infiltrating the work on country-specific situations, special sessions and undermining the role of NGOs. The advancement of national agendas unrelated to human rights, it seems, is a major factor that undermines intergovernmental human rights bodies at the UN, perhaps demonstrating a need to revisit the discussion on whether governmental representatives or independent experts are the most effective delegates to such an institution. Or perhaps it is simply time to accept that the UN's main human rights body cannot be expected to be, let alone tasked with, independent, impartial and objective protection and promotion of human rights - a sorry state of affairs, but one that reflects the reality of the situation. 